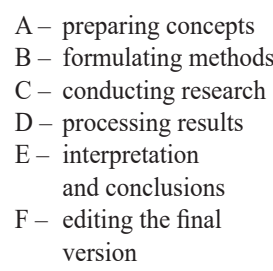

\section{Physical activity and injuries relating to physical fitness of professional firefighters}

\section{Aktywność fizyczna oraz urazy w relacji do sprawności fizycznej zawodowych strażaków}

\begin{abstract}
Agnieszka Magdalena Nowak ${ }^{1 *}$ A-F, Bartosz Molik ${ }^{2}$ A-F, Agnieszka Wójcik ${ }^{3 B}$, Izabela Rutkowska ${ }^{2 B}$, Sylwia Nowacka-Dobosz ${ }^{5 B}$, Marek Kowalczyk ${ }^{4 F}$, Jolanta Marszałek 2 A-F
\end{abstract}

Jozef Pilsudski University of Physical Education in Warsaw, Poland; Akademia Wychowania Fizycznego Józefa Piłsudskiego w Warszawie, Polska

${ }^{1}$ Faculty of Rehabilitation, Chair of Movement Teaching, Department of Movement Teaching for the Disabled; Wydział Rehabilitacji, Katedra Nauczania Ruchu, Zakład Nauczania Ruchu Osób Niepełnosprawnych

${ }^{2}$ Faculty of Rehabilitation, Chair of Movement Teaching, Department of Disability Sport, Wydział Rehabilitacji, Katedra Nauczania Ruchu, Zakład Sportu Niepełnosprawnych

${ }^{3}$ Faculty of Rehabilitation, Chair of Physiotherapy, Department of Clinical Bases of Physiotherapy, Wydział Rehabilitacji, Katedra Fizjoterapii, Zakład Klinicznych Podstaw Fizjoterapii

${ }^{4}$ Faculty of Rehabilitation, Chair of Physiotherapy, Department of Physical Therapy and Massage; Wydział Rehabilitacji, Katedra Fizjoterapii, Zakład Fizykoterapii i Masażu

${ }^{5}$ Faculty of Physical Education, Chair of Humanities and Social Sciences, Department of Physical Education Theory and Methodology; Wydział Wychowania Fizycznego, Katedra Nauk Humanistycznych i Społecznych, Zakład Teorii i Metodyki Wychowania Fizycznego

\title{
Abstract
}

Introduction: The profession of a firefighter involves multiple factors that directly or indirectly impact on the person's health. The aim of this study was to establish the correlation between physical fitness of the selected group of firefighters with respect to anthropometric parameters, additional physical activity, and injury rate.

Material and methods: The study examined 77 men who worked for the State Fire Service (age: $28.87 \pm 9.84$ years, body mass: $82.13 \pm 9.37 \mathrm{~kg}$, body height: $180.12 \pm 6.39 \mathrm{~cm}$ ). Of he study group, $53 \%$ of the fire-fighters had normal BMI, $42 \%$ were overweight and $5 \%$ had first degree obesity. The study used a survey questionnaire concerning the anthropometric data, previous injuries, physiotherapeutic procedures following the injury, and participants' involvement in additional physical activity. A physical fitness test battery was used to determine the correlation between physical fitness and: age, BMI and additional physical activity and injury rate.

email: agny.nowak@gmail.com 
Key words:

\section{Słowa kluczowe:}

Results: Musculoskeletal injuries accounted for $51 \%$ of all injuries. Of all injuries, $56 \%$ were occupational. The correlations between the results of the handgrip test were insignificant with respect to BMI and age, whereas in other tests, the correlations were statistically significant $(p<0.05)$. No differences were observed in the results of handgrip test between the group of firefighters who were and those who were not involve in additional physical activity. Comparison of the results obtained by firefighters following the injury and without previous injuries revealed a statistically significant difference $(\mathrm{p}<0.05)$ in the $4 \times 10 \mathrm{~m}$ shuttle run.

Conclusions: Age and higher values of BMI are the factors that reduce the level of physical fitness of firefighters. Involvement in additional physical activity is a factor in improving physical fitness of firefighters. Previous injuries the firefighters had suffered did not have an effect on their physical fitness.

\section{physical fitness, firefighters, injuries, illness, fire service}

\section{Streszczenie}

Wstęp: Zawód strażaka naraża go na wiele czynników, które bezpośrednio lub pośrednio wpływają na jego zdrowie. Celem pracy było określenie związku między sprawnością fizyczną wybranej grupy strażaków w relacji do parametrów antropometrycznych, podejmowanej dodatkowej aktywności fizycznej i urazowości.

Materiat i metody: W badaniu wzięło udział 77 mężczyzn, funkcjonariuszy Państwowej Straży Pożarnej (wiek 28,87 $\pm 9,84$ lat, masa ciała $82,13 \pm 9,37 \mathrm{~kg}$, wysokość ciała $180,12 \pm 6,39 \mathrm{~cm}) .53 \%$ badanych strażaków mieściła się w normie wskaźnika BMI, 42\% miała nadwagę, a u 5\% osób stwierdzono otyłość I stopnia. Wykorzystano kwestionariusz ankiety dotyczący danych antropometrycznych, przebytych urazów, przebytej rehabilitacji po urazie, podejmowania dodatkowej aktywności fizycznej przez badanych. Do określenia związku między sprawnością fizyczną a wiekiem, BMI, podejmowaniem dodatkowej aktywności fizycznej i urazowości wykorzystano baterię testów sprawności fizycznej.

Wyniki: Urazy mięśniowo-szkieletowe stanowiły 51\% wszystkich urazów. 56\% ze wszystkich urazów była związana $\mathrm{z}$ wykonywaną pracą. Związki między wynikami w teście siły chwytu ręki są nieistotne $\mathrm{w}$ odniesieniu do BMI i wieku, zaś w pozostałych testach związki były istotne statystycznie $(\mathrm{p}<0,05)$. Nie zaobserwowano różnicy w wynikach testu siły chwytu ręki między grupą strażaków podejmujących i niepodejmujących dodatkowej aktywności fizycznej. Porównując wyniki strażaków po przebytym urazie i bez przebytego urazu znaleziono różnicę istotną statystycznie $(\mathrm{p}<0,05) \mathrm{w}$ biegu wahadłowym 4 × $10 \mathrm{~m}$.

Wnioski: Wiek oraz wyższe wartości BMI są czynnikami obniżającymi poziom sprawności fizycznej strażaków. Podejmowanie dodatkowej aktywności fizycznej jest czynnikiem wpływającym na poprawę sprawności fizycznej strażaków. Urazy przebyte przez strażaków nie mają wpływu na poziom sprawności fizycznej strażaków.

sprawność fizyczna, strażacy, urazy, choroba, straż pożarna

\section{Introduction}

Profession of a firefighter involves the exposure of a person to unfavourable environmental effects, such as toxic substances (carbon oxide, hydrogen cyanide) [1], insufficient oxygen supply and high level of thermal radiation [2-4]. An additional load during firefighting operations is firefighting equipment and bunker gear that weighs from 20 to $40 \mathrm{~kg}$ [1,3-6].
During work, firefighters are exposed to many stress-inducing conditions [7]. These include insufficient and irregular physical activity, unhealthy eating habits (foods poor in nutrients, fast foods) [8], sleep deprivation [8,9], chronic stress that influences quality of sleeping and health status [10], waiting in readiness (psychical and physical stress), noise [11], toxic fumes and hazardous combustion products [2], excess heat leading to hyperthermia 
$[12,13]$ and cardiovascular diseases $[2,7,14,15]$, and dehydration $[5,16]$. Furthermore, firefighters have been found to be dehydrated even before firefighting operations, which is especially dangerous during the operation and has a negative effect on human body [17-19].

Due to the exposure to so many dangerous stressors during firefighting work, it was found that with insufficient prevention, firefighters' health is at risk [7]. Firefighters are at increased risk of cardiovascular diseases $[7,20]$, respiratory system diseases, cancers, hearing impairment [20], obesity $[2,7,14,15,21]$, and arterial hypertension [7]. It was observed that the risk of developing posttraumatic stress disorder is elevated in firefighters, with all the related health effects $[22,23]$. The statistics in the USA showed that $51 \%$ deaths of firefighters in 2015 were on-duty sudden cardiac deaths [24], a key factor in their mortality rates. This condition is caused by ischaemic heart disease rather than, as it would seem, the risks involved in extinguishing the fires and inhalation of toxic fumes or smoking [6].

Overweight and obesity have been identified as a determining risk factor in occupational health and safety of firefighters [2,7,14,15,25]. Low level of physical activity has a significant effect on increased fat mass and prevalence of metabolic syndromes [7]. Studies have found that over their careers, firefighters put on weight by ca. 0.5 to $1.6 \mathrm{~kg}$ a year [26,27]. Jahnke et al. (2013) recommend taking additional physical activity by firefighters in order to improve body composition in this population and as a method to prevent injuries. These researchers demonstrated that obese $\left(B M I \geq 30 \mathrm{~kg} / \mathrm{m}^{2}\right.$, waist circumference $>102 \mathrm{~cm}$ ) firefighters were at 5.2 times higher risk of musculoskeletal injuries compared to their peers with normal body mass (BMI 18.5-24.9 kg/m²) and three times more prone to injuries [15]. Other authors emphasized that body mass reduction leads to lower injury rates in the population of firefighters, even by $60 \%$ [25].

In 2012, 1.1 million professional firefighters received around 69,400 injuries in the USA, which means 6.1 injury per 100 firefighters [28]. The most prevalent injuries were: muscle strains, joint sprains [29], open wounds, concussions [15,29], fractures, and internal injuries [15]. According to Lee et al. (2004), firefighters aged 30-39 years are mostly hospitalized due to the occupational risks, with most frequent problems being joint overload and sprains, exhaustion and burns [30]. Injuries and diseases, including diseases of musculoskeletal system, and fatigue connected with working in difficult conditions, lead to deterioration of physical fitness and health of firefighters [20]. From 30 to $40 \%$ musculoskeletal injuries were occupational $[28,29]$. Furthermore, $31-33 \%$ of injuries were connected with physical exercises $[15,29]$. It was also demonstrated that exercises were a leading cause of on-duty injuries [29]. Another study found that the risk of injury related to physical activity was increasing with longer duration of weekly physical activity and level of cardiorespiratory capacity [31]. It is also known that irregular and insufficient volume of physical activity is typical of people who work in fire service [7].

The problems of physical fitness of people working in fire service have been discussed by many authors who used various physical fitness tests. Firefighters were examined by means of Fit for Duty (FFD) test [4,32,33], Pack Hike Test (PHT) [34], and Field Walk Test (FWT) [35,36]. Other tests presented in the literature were the Firefighter Emergency Abilities and Tasks test (FEAT test) [12], Predictor Test Battery [37], Ability Test (AT) [4], and CPAT test [38]. All the above test batteries contain tasks to be performed which are similar to those firefighters face during firefighting operations (the tests are characterized by the exercise similar to that observed during firefighting operations). The tests evaluate individual firefighting skills and components of physical fitness. The FFD test evaluates individual abilities to perform work $[4,33]$. The PHT test is an equivalent of the FFD and also evaluates the firefighter's preparation to be involved in firefighting operations [34]. The FWT is a simplified form of the PHT [35] and is used by people who have lower occupational load [36]. Mendenhall et al. (2005), Boyd et al. (2015) and Fullagar et al. (2015) used the test battery composed of several tests that simulated the load and tasks in work of firefighters [39-41].

The CPAT test is a screening test of minimal physical abilities required from candidates for firefighters and contains the tasks that simulate what happens during a firefighting operation [38]. The AT test represents a combination of simulated firefighting tasks with typical physical fitness tests such as sit-ups in 1 minute, push-ups to exhaustion, sit-and-reach test, 1RM bench press, and barbell squat [4]. The Modified Canadian Aerobic Fitness Test's (mCAFT) was also used to evaluate $\mathrm{VO}_{2 \max }$ 
with the measurement of the strength of lower and upper limbs and simulated firefighting tasks [42].

Other reports concerned the use of physical fitness tests among firefighters $[6,32,43,44]$. Storer et al. (2014) used the following tests of muscle strength and flexibility: handgrip test, pushups, sit-ups in 1 minute and speed push-ups [6]. Claessens et al. (2003) examined physical fitness in professional fire-fighters using tests from the Eurofit test battery: sit-and-reach test, standing broad jump, handgrip test, sit-ups, bent arm hang, $10 \times 5 \mathrm{~m}$ shuttle run, endurance shuttle run [43]. Physical fitness tests performed by Rhea et al. (2004) that measured endurance, muscle strength, local strength endurance and body composition included: 12-minute Cooper test, $400 \mathrm{~m}$ run, bench press, squats with free weights, lifting the dumbbells to chest with body bent forwards with the dominant hand, sitting dumbbell press, sit-ups to exhaustion, handgrip endurance test $[32,44]$. Overview of literature indicates variety of physical fitness tests used in the examinations of firefighters.

To date, the focus has been mainly on developing various physical fitness tests for firefighters and verification of their usefulness. However, physical fitness has not been evaluated in this group and the correlations of anthropometric parameters with physical activity and injuries have not been examined. Therefore, the aim of this study was to establish the correlation between physical fitness of the selected group of firefighters with respect to anthropometric parameters, additional physical activity, and injury rate.

\section{Material and Methods}

The examinations were conducted in a group of 77 men aged 19 to 50 years in 2016. Mean age was $28.87 \pm 9.84$ years, mean body mass was $82.13 \pm 9.37 \mathrm{~kg}$ and mean body height was $180.12 \pm 6.39 \mathrm{~cm} .53 \%$ of the firefighters had normal BMI $\left(18.51-24.99 \mathrm{~kg} / \mathrm{m}^{2}\right)$. Furthermore, $42 \%$ of them were overweight $\left(25.00-29.99 \mathrm{~kg} / \mathrm{m}^{2}\right)$, and $5 \%$ of them were obese (first degree obesity, 30.00$34.99 \mathrm{~kg} / \mathrm{m}^{2}$ ). The men worked for the State Fire Service in Poland and were on active duty. Mean working experience was $8.25 \pm 8.97$ years.

The study used a survey questionnaire concerning the anthropometric data, previous injuries, physiotherapeutic procedures following the injury, and participants' involvement in additional physical activity. Injury was defined as: "damage to tissues or body organs due to local or general effect of an external factor" [45].

Based on the expert analysis, the study used the test battery containing the following tests: handgrip test (static handgrip strength) [46,47], pull-ups (upper limb strength) [48], sit-ups (strength endurance of the abdominal muscles) [46-48], bent arm hang (strength endurance of arms), standing broad jump (explosive strength), endurance shuttle run (endurance) [46,47], medicine ball throw with both hands from the chest (explosive strength), back medicine ball throw with both hands (explosive strength) [48], $10 \times 5 \mathrm{~m}$ shuttle run (speed endurance) $[46,47], 4 \times 10 \mathrm{~m}$ shuttle run (speed endurance) [48], $50 \mathrm{~m}$ run (speed) [48], 1,000 $\mathrm{m}$ run (endurance) [48].

The $4 \times 10 \mathrm{~m}, 10 \mathrm{x} 5 \mathrm{~m}, 50 \mathrm{~m}$, and $1000 \mathrm{~m}$ runs were measured by means of: Witty System photocells (electronic time measurement system with accuracy of up to $0.01 \mathrm{~s}$ ) and Witty Manager software (version 1.4.1) for endurance shuttle run (number of distances run), multimedia equipment for playing the recordings of the Eurofit endurance shuttle run, colloquially termed the beep test, a $3 \mathrm{~kg}$ medicine ball for distance throw test (results given with accuracy of $0.01 \mathrm{~m}$ ), hydraulic dynamometer for the measurement of handgrip strength (results given in $\mathrm{N}$ ).

The tests were performed over one day. Firefighters arrived in groups at specified days. They were wearing sports clothing. The tests were always performed with the same order and in the gymnasium. Prior to performance of the tasks, the firefighters were given detailed instructions concerning performance of each test and followed a warm-up protocol (10-minute warm up using body movements: jogging, high kicks, upper limb swings, rotations in lower limb joints, body trunk and upper limbs). The participants had a 15 minute rest.

The examinations were approved by the ethical committee and each participant gave written informed consent.

\section{Statistical analysis}

The results documented for the groups involved in additional physical activity and those who were not involved in any additional activity and the groups after previous injuries and without injuries were compared with each other. The non-parametric Mann-Whitney U test was used for the purpose. The results at the level of $p<0.05$ were considered statistically significant. 
The correlations of age and BMI with the study results were established using the Spearman's rank correlation coefficient. The statistical significance was set at $\mathrm{p}<0.05$, where: $0.4<|\mathrm{r}| \leq 0.7$ is a moderate correlation, $0.7<|\mathrm{r}|<1$ is strong correlation, $|\mathrm{r}|=1$ is full correlation [49].

The dependent variables were the results obtained in physical fitness tests. The independent variables were BMI, age of participants, their association with the groups of people involved and those not involved in additional physical activity and association with the groups due to previous injuries or no previous injuries.

\section{Results}

Involvement in additional physical activity was declared by 63 of 77 firefighters, whereas mean number of hours of this activity per week was 5.95.

Previous injuries were reported by 43 people (musculoskeletal injuries: $\mathrm{n}=22 ; 51 \%$, fractures: $n=7 ; 16 \%$, other: $n=14 ; 33 \%)$. In 24 people $(54 \%)$, injuries were occupational. Other participants $(n=19)$ did not specify the circumstances of their injuries. $44 \%$ of the participants $(n=19)$ had undergone physiotherapeutic procedures. Among these people, $64 \%(n=12)$ continued to suffer from some problems (injuries made it harder for them to perform the activities of daily living and vocational activities). Based on the replies contained in the questionnaires, the participants were divided, for the purposes of statistical analysis, to the following groups: involved/not involved in additional physical activity, and with or without previous injuries.

No correlation was shown for the results of the handgrip test with age and BMI. A weak negative correlation was found between the results in the back medicine ball throw and age $(\mathrm{r}<0.4, \mathrm{p}<0.05)$, with poorer throwing performance observed with age. A weak negative correlation was found between the results in the back medicine ball throw and age ( $r>0.7$ and $r>0.6$, respectively, $p<0.05$ ). It was demonstrated that older firefighters and those with higher BMI had worse results in the sit-ups test. Moderate negative correlations were found for the results in the following tests: pull-ups (upper limb strength), sit-ups (strength endurance of the abdominal muscles) bent arm hang (strength endurance of arms), standing broad jump (explosive strength), endurance shuttle run (endurance), medicine ball throw with both hands from the chest (explosive strength), back medicine ball throw with both hands (explosive strength) with age and BMI. A moderate positive correlation was found for the results in the tests: $10 \times 5 \mathrm{~m}$ shuttle run (speed endurance), 4 x $10 \mathrm{~m}$ shuttle run (speed endurance) [48], $50 \mathrm{~m}$ run (speed) and 1,000 $\mathrm{m}$ run (endurance) with age and BMI. All the correlations between the results obtained in physical fitness tests and age and BMI of firefighters are presented in Table 1.

Tab. 1. Correlations of age and BMI with the results obtained in physical fitness tests of firefighters (the Spearman's rank correlation coefficient)

\begin{tabular}{|c|c|c|c|}
\hline Physical fitness test & & Age (years) & BMI $\left(\mathrm{kg} / \mathrm{m}^{2}\right)$ \\
\hline \multirow{2}{*}{ Handgrip strength $[\mathrm{N}]$} & $\mathrm{r}$ & 0.083 & 0.148 \\
\hline & $\mathrm{p}$ & s.i. & s.i. \\
\hline \multirow{2}{*}{ Pull-ups [repetitions] } & $\mathrm{r}$ & -0.625 & -0.535 \\
\hline & $\mathrm{p}$ & $*$ & $*$ \\
\hline \multirow{2}{*}{ Sit-ups [repetitions] } & $\mathrm{r}$ & -0.768 & -0.627 \\
\hline & $\mathrm{p}$ & $*$ & $*$ \\
\hline \multirow{2}{*}{ Endurance shuttle run [number of sections] } & $\mathrm{r}$ & -0.512 & -0.493 \\
\hline & $\mathrm{p}$ & $*$ & $*$ \\
\hline \multirow{2}{*}{ Standing long jump $[\mathrm{m}]$} & $\mathrm{r}$ & -0.614 & -0.513 \\
\hline & $\mathrm{p}$ & $*$ & $*$ \\
\hline \multirow{2}{*}{ Medicine ball throw with both hands from the chest $[\mathrm{m}]$} & $\mathrm{r}$ & -0.479 & -0.129 \\
\hline & $\mathrm{p}$ & $*$ & s.i. \\
\hline \multirow{2}{*}{ Back medicine ball throw with both hands $[\mathrm{m}]$} & $\mathrm{r}$ & -0.396 & -0.043 \\
\hline & $\mathrm{p}$ & $*$ & s.i. \\
\hline \multirow{2}{*}{ Bent arm hang $[\mathrm{s}]$} & $\mathrm{r}$ & -0.478 & -0.618 \\
\hline & $\mathrm{p}$ & $*$ & $*$ \\
\hline \multirow{2}{*}{$10 \times 5 \mathrm{~m}$ shuttle run $[\mathrm{s}]$} & $\mathrm{r}$ & 0.487 & 0.377 \\
\hline & $\mathrm{p}$ & $*$ & $*$ \\
\hline \multirow{2}{*}{$4 \times 10$ m shuttle run $[\mathrm{s}]$} & $\mathrm{r}$ & 0.570 & 0.441 \\
\hline & $p$ & $*$ & $*$ \\
\hline \multirow{2}{*}{$50 \mathrm{~m}$ run $[\mathrm{s}]$} & $\mathrm{r}$ & 0.590 & 0.543 \\
\hline & $\mathrm{p}$ & $*$ & $*$ \\
\hline \multirow{2}{*}{$1000 \mathrm{~m}$ run $[\mathrm{s}]$} & $\mathrm{r}$ & 0.569 & 0.504 \\
\hline & $\mathrm{p}$ & $*$ & $*$ \\
\hline
\end{tabular}

\footnotetext{
* significant correlation at $\mathrm{p}<0,05$; s.i. - statistically insignificant correlation
} 
Statistically significant differences were demonstrated between the results of firefighters that were and those who were not involved in additional physical activity in all tests except for one: handgrip test $(\mathrm{p}>0.05)$. Firefighters involved in additional physical activity showed better performance in the tests: pull-ups (upper limb strength), sit-ups (strength endurance of the abdominal muscles) and endurance shuttle run, and also standing broad jump (explosive strength), medicine ball throw with both hands from the chest (explosive strength) and back medicine ball throw with both hands (explosive strength) compared to those who were not involved in such activities. Table 2 presents other results in physical fitness tests.

Tab. 2. Mean results and standard deviations and indices of statistical significance of differences between the physical fitness test results in the groups of firefighters involved and those not involved in additional physical activity

\begin{tabular}{|c|c|c|c|c|}
\hline \multirow[t]{2}{*}{ Physical fitness test } & $\begin{array}{l}\text { People involved in additional } \\
\text { physical activity }\end{array}$ & $\begin{array}{l}\text { People not involved in } \\
\text { additional physical activity }\end{array}$ & \multirow[t]{2}{*}{ Z } & \multirow[t]{2}{*}{$\mathrm{p}$} \\
\hline & $\tilde{\mathrm{X}} \pm \mathrm{SD}$ & $\tilde{\mathrm{x}} \pm \mathrm{SD}$ & & \\
\hline Handgrip strength [N] & $1054.30 \pm 166.43$ & $1028.19 \pm 162.28$ & -0.653 & s.i. \\
\hline Pull-ups [repetitions] & $10.21 \pm 5.70$ & $4.29 \pm 4.46$ & -3.326 & $*$ \\
\hline Sit-ups [repetitions] & $56.00 \pm 16.40$ & $35.80 \pm 14.10$ & -3.878 & $* *$ \\
\hline Endurance shuttle run [number of sections] & $71.03 \pm 21.10$ & $46.94 \pm 15.25$ & -3.876 & $* *$ \\
\hline Standing long jump $[\mathrm{m}]$ & $2.42 \pm 0.23$ & $2.13 \pm 0.23$ & -4.019 & $* *$ \\
\hline Medicine ball throw with both hands from the chest [m] & $8.27 \pm 1.28$ & $7.09 \pm 1.06$ & -3.130 & $*$ \\
\hline Back medicine ball throw with both hands [m] & $12.46 \pm 1.74$ & $10.99 \pm 1.77$ & -2.842 & $*$ \\
\hline Bent arm hang [s] & $28.46 \pm 13.62$ & $19.38 \pm 12.71$ & -2.166 & $*$ \\
\hline $10 \times 5 \mathrm{~m}$ shuttle run $[\mathrm{s}]$ & $17.59 \pm 0.75$ & $18.50 \pm 1.14$ & -3.145 & $*$ \\
\hline $4 \times 10 \mathrm{~m}$ shuttle run $[\mathrm{s}]$ & $10.80 \pm 0.57$ & $11.53 \pm 0.62$ & -4.012 & $* *$ \\
\hline $50 \mathrm{~m}$ run $[\mathrm{s}]$ & $7.39 \pm 0.51$ & $7.99 \pm 0.58$ & -3.685 & $* *$ \\
\hline $1000 \mathrm{~m}$ run $[\mathrm{s}]$ & $232.15 \pm 33.15$ & $276.96 \pm 37.95$ & -3.974 & $* *$ \\
\hline
\end{tabular}

$\tilde{\mathrm{x}}$ - mean value; $\mathrm{SD}$ - standard deviation; ${ }^{*} \mathrm{p}<0.05 ; * * \mathrm{p}<0.001 ;$ s.i. - statistically insignificant differences

Comparison of the results of physical fitness tests of firefighters after previous injuries or without previous injuries revealed a statistically significant difference $(p<0.05)$ between these groups in the results of $4 \times 10 \mathrm{~m}$ (speed endurance), with the

group after previous injuries having worse mean time $(11.09 \mathrm{~s})$ compared to the group of people without injuries (10.76 s). No statistically significant differences were found in other results of physical fitness tests (see Table 3).

Tab. 3. Mean results and standard deviations and indices of statistical significance of differences between the physical fitness test results for the firefighters who had and those who had not suffered from injuries

\begin{tabular}{|c|c|c|c|c|}
\hline \multirow{2}{*}{ Physical fitness test } & People after injuries (n=x) & $\begin{array}{c}\text { People without previous } \\
\text { injuries }\end{array}$ & \multirow{2}{*}{$Z$} & \multirow{2}{*}{$\mathrm{p}$} \\
\cline { 2 - 4 } & $\tilde{\mathrm{x}} \pm \mathrm{SD}$ & $\tilde{\mathrm{x}} \pm \mathrm{SD}$ & & \\
\hline Handgrip strength [N] & $1059.21 \pm 183.87$ & $1035.79 \pm 138.76$ & -0.067 & s.i. \\
\hline Pull-ups [repetitions] & $8.27 \pm 6.01$ & $10.12 \pm 5.78$ & -1.387 & s.i. \\
\hline Sit-ups [repetitions] & $48.81 \pm 17.35$ & $56.18 \pm 17.83$ & -1.536 & s.i. \\
\hline Endurance shuttle run [number of sections] & $63.45 \pm 24.57$ & $69.00 \pm 18.78$ & -1.159 & s.i. \\
\hline Standing long jump [m] & $2.33 \pm 0.28$ & $2.40 \pm 0.23$ & -0.985 & s.i. \\
\hline Medicine ball throw with both hands from the chest [m] & $8.06 \pm 1.42$ & $7.97 \pm 1.21$ & -0.005 & s.i. \\
\hline Back medicine ball throw with both hands [m] & $12.44 \pm 1.93$ & $11.80 \pm 1.66$ & -1.416 & s.i. \\
\hline Bent arm hang [s] & $23.98 \pm 13.72$ & $30.00 \pm 13.46$ & -1.677 & s.i. \\
\hline $10 \times 5$ m shuttle run [s] & $17.87 \pm 1.01$ & $17.66 \pm 0.79$ & -0.862 & s.i. \\
\hline $4 \times 10 \mathrm{~m}$ shuttle run [s] & $11.09 \pm 0.68$ & $10.76 \pm 0.57$ & -2.237 & $*$ \\
\hline $50 \mathrm{~m}$ run [s] & $7.62 \pm 0.61$ & $7.38 \pm 0.50$ & -1.677 & s.i. \\
\hline $1000 \mathrm{~m}$ run [s] & $247.35 \pm 41.40$ & $234.02 \pm 33.77$ & -1.359 & s.i. \\
\hline
\end{tabular}

$\tilde{\mathrm{x}}$ - mean value; $\mathrm{SD}$ - standard deviation; ${ }^{*} \mathrm{p}<0.05 ;{ }^{*} \mathrm{p}<0.001$; s.i. - statistically insignificant differences 


\section{Discussion}

The aim of this study was to establish the correlation between physical fitness of the selected group of firefighters with respect to anthropometric parameters, additional physical activity, and injury rate. Most previous studies have been devoted to the choice of physical fitness tests for evaluation of physical load in the work of firefighters, analysis of tests that simulate firefighting-specific load in terms of their usefulness and reliability and the risk of cardiovascular diseases in firefighters. The examinations were mainly from Australia, Canada, and the USA. The only examinations that were found concerned screening tests of physical fitness of firefighters using selected components of Eurofit test battery [43]. The tests demonstrated that physical fitness is reduced with age. This conclusion was consistent with our study.

Although statistically insignificant correlations were found between handgrip strength and age and between handgrip strength and BMI, one of the authors justified using this test by the risk of injuries related to the use of hands during firefighting activities [6]. A weak correlation between handgrip and age $(\mathrm{r}=-0.250, \mathrm{p}<0.01)$ was demonstrated by Walker et al. (2014). These researchers examined firefighters with mean age of 39 years, whereas mean age in our study was 28.9 years. A substantial decline in strength was found in the group of people aged 35 to 54 years, whereas the difference was not statistically insignificant in younger participants [21]. Methodology of handgrip test was different between the study by Walker et al. (2014) and our study. In the present study, the test was performed while standing, with upper limb along the body, whereas Walker et al. (2014) had their athletes perform the test in a sitting position with elbow bent to 90 degrees [21].

We used 12 tests to examine physical fitness in firefighters. It is difficult to compare the results to those obtained by other authors since different physical fitness tests were used, the authors defined different study aims or used different methodologies, which was also reported by Claessens et al. (2003) [43]. We counted the number of sections covered in the endurance shuttle run, whereas Claessens (2003) counted the run time in minutes [43]. Storer et al. (2014) evaluated abdominal muscle endurance by counting sit-ups in 1 minute ( $47 \pm 23$ repetitions) [6], whereas in the present study, we measured the number of repetitions in 2 minutes $(52 \pm 17$ repetitions). It is unclear what Storer et al. (2014) considered a complete repetition [6].

A high level of physical fitness is related to effective performance of professional duties of firefighters [4,32]. Numerous researchers have found that the major problem in the group of firefighters is overweight $[6,7,14,21,27]$. Around a third of firefighters in most studies were categorized as degree 1 obesity. Furthermore, 73 to $88 \%$ of participants had BMI above $25[4,7,14,50]$. Our own study demonstrated deteriorated physical fitness with age and with increasing body mass. It was shown that $42 \%$ of firefighters were overweight (BMI $>25)$, whereas $5 \%$ developed type 1 obesity (BMI $>30$ ), with 53\% having normal BMI. The study of Subramaniam et al. (2012) also found that firefighting teams with greater mean body mass and higher level of physical fitness demonstrated better initial emergency response performance [44]. Williford et al. (1999) examined firefighters and found that the greater body mass of a person the better results in tests simulating firefighting activities during emergency operations and rescue exercises described in the introduction section [51]. The people in professional groups which are likely to have greater muscle mass, such as athletes, policemen or firefighters, may be more prone to incorrect classification as overweight or obese using only BMI index [52,53]. Many authors have emphasized that in addition to BMI, one should also analyse body fat percentage $(\mathrm{BF} \%)$ of the participants $[14,44,50]$.

Furthermore, Jahnke et al. (2013) found that obese firefighters (BMI $\geq 30$, waist circumference $>102 \mathrm{~cm}$ ) were at 5.2 times higher risk of musculoskeletal injuries compared to their peers with normal body mass (BMI 18.5-24.9 kg/m²) [15]. Obesity leads to serious consequences for firefighters in the form of elevated risk of occupational injuries [27] and has been identified as a substantial problem and a determining risk factor in occupational health and safety of firefighters $[14,25]$. The findings presented by Jahnke et al. (2013) suggested that physical activity started in order to prevent injuries may help improve body composition in this population [15].

Statistics show that ca. 80,000 firefighters suffer injuries every year. Over $40 \%$ of injuries are occupational, although firefighters spend little time at activities related to firefighting. Per 1000 fires, 23 to 25 firefighters receive injuries, whereas only 
0.6 to 0.7 injuries per 1,000 do not concern firefighting operations [28]. Another study showed that a lower level of physical fitness is related to elevated injury risk $[20,54]$ and diseases, including musculoskeletal diseases, occupational fatigue states due to high temperature and unfavourable working conditions typical of the work of a firefighter [20].

It was observed in longitudinal studies that the most frequentbody injuriesinfirefightersaremusculoskeletal injuries (67\%) [29], which is consistent with our findings. The most prevalent injuries were dislocations and sprains $(65.4 \%)$, whereas the most frequent mechanism of injury was acute excessive exercise $(67.9 \%)$, with the most frequent injury locations being lower limbs (61.7\%) [55].

Poplin et al. (2012) demonstrated that 30\% injuries were occupational, whereas $89 \%$ were related to physical exercises [29]. The data published by Soteriades et al. (2008) showed that injury rate was at the level of 90/1000 firefighters for musculoskeletal injuries over the period of 12 months. These authors suggested that if all firefighters had had BMI at the level of 25 or less, the musculoskeletal injury rate would have declined to $60 \%$ i.e. it would translate into 54 injury cases per 1000 firefighters over 12 months [25].

Our study demonstrated that nearly every second firefighter suffers an injury and almost every second injury is occupational. Substantial body mass represents a greater load to the locomotor system $[15,25]$, and the firefighter is additionally loaded with bunker gear and equipment that they have to carry during firefighting operations, exceeding $20 \mathrm{~kg}$ (only bunker gear with breathing apparatus) [1,3-6].

In our study, nearly half of the firefighters who had suffered injuries underwent physiotherapeutic procedures. No studies were found to examine the effect of physiotherapy on injuries in the groups of professional firefighters. It is also impossible to evaluate the effectiveness of physiotherapy because of no information about how the therapies were organized and what the procedures had been and how conscientiously the firefighters had followed the recommendations of physiotherapists.

Due to the specific nature of firefighting work, firefighters have to maintain a high level of muscle strength and physical fitness [6,32], and sufficient body mass and composition [6]. In the past, training programs for firefighters used to focus mainly on cardiovascular endurance and muscle strength. If aerobic and anaerobic endurance is neglected, effectiveness of firefighting activities deteriorates, leading to injuries among firefighters. It is important that the elements of firefighting training should affect all the areas of fitness [32]. Griffin et al. (2015) developed the fitness program for firefighters named the Probationary Firefighter Fitness (PFF-Fit). A reduction in injury rates and costs of insurance compensations was observed in participants following the PFF-Fit. It was found that PFFFit can be effective in limitation of compensation costs. Further research is needed to provide insight into the present and other interventions in terms of health and physical fitness with longer periods of observation in order to evaluate potential effects among new recruits [55].

Recommendation to future studies and limitation of the current study

Educational activities concerning promotion of healthy lifestyles should be implemented and training programs should be developed to meet the demands of the specific nature of work and physical load of firefighters. One limitation of the study is the lack of identification of the criterion concerning a minimal time of additional physical activity since division into groups was based on declarations in the questionnaire forms. In the future, the group of firefighters studies should be more homogenized in terms of work experience and age, whereas body composition examinations should be more advanced (based not only on BMI).

\section{Conclusions}

1. Age and higher values of BMI are the factors that reduce the level of physical fitness of firefighters.

2. Involvement in additional physical activity is a factor in improving physical fitness of firefighters.

3. Previous injuries the firefighters had suffered did not have an effect on their physical fitness. 


\section{References:}

1. Smith DL. Firefighter fitness: improving performance and preventing injuries and fatalities. Curr Sports Med Rep. 2011;10(3):167-72.

2. Fogleman M, Bhojani FA. Refinery firefighters: Assessing fitness for duty. Int J Occup Saf Ergon. 2005;11(2):161-70.

3. von Heimburg ED, Rasmussen AKR, Medbø JI. Physiological responses of firefighters and performance predictors during a simulated rescue of hospital patients. Ergonomics. 2006;49(2):111-26.

4. Michaelides MA, Parpa KM, Thompson J, Brown B. Predicting performance on a firefghter's ability test from fitness parameters. Res Q Exerc Sport. 2008;79(4):468-75.

5. Selkirk GA, McLellan TM, Wong J. Active versus passive cooling during work in warm environments while wearing firefighting protective clothing. J Occup Environ Hyg. 2004;1:521-31.

6. Storer TW, Dolezal BA, Abrazado ML, Smith D.L, Batalin MA, Chi-Hong Tseng, Cooper CB. Firefighter health and fitness assessment: a call to action. J Strength Cond Res. 2014;28(3):661-71.

7. Soteriades ES, Smith DL, Tsismenakis AJ, Baur DM, and Kales SN. Cardiovascular disease in US firefighters: a systematic review. Cardiological Review. 2011;19:202-15.

8. Lowden A, Moreno C, Holmback U, Lennernas M, Tucker P. Eating and shift work - effects on habits, metabolism and performance. Scand J Work Environ Health. 2010;36:150-62.

9. Puttonen S, Harma M, Hublin C. Shift work and cardiovascular disease - pathways from circadian stress to morbidity. Scand J Work Environ Health. 2010;36:96-108.

10. de Lange AH, Kompier MA, Taris TW, Geurts SA, Beckers DG, Houtman IL, Bongers PM. A hard day's night: a longitudinal study on the relationships among job demands and job control, sleep quality and fatigue. J Sleep Res. 2009;18:374-83.

11. Kales SN, Tsismenakis AJ, Zhang C, Soteriades ES. Blood pressure in firefighters, police officers, and other emergency responders. Am J Hypertens. 2009;22:11-20.

12. Smith DL, Petruzzello SJ, Chludzinski MA, Reed JJ, Woods JA. Selected hormonal and immunological responses to strenous live-fire firefighting drills. Ergonomics. 2005;48:55-65.

13. Carter JM, Rayson MP, Wilkinson DM, Blacker SD. Strategies to combat heat strain during and after firefighting. J Therm Biol. 2007;109-16.

14. Poston WSC, Haddock CK, Jahnke SA, Jitnarin N, Tuley BC, Kales SN. The prevalence of overweight, obesity, and substandard fitness in a population-based firefighter cohort. J Occup Environ Med. 2011;53:266-73.

15. Jahnke SA, Poston WS, Haddock CK, Jitnarin N, Obesity and incident injury among career firefighters in the central United States. Obesity. 2013;21:1505-8.

16. Smith DL, Manning TS, Petruzzello SJ. Effect of strenuous live-fire drills on cardiovascular and psychological responses of recruit firefighters. Ergonomics. 2001;44:244-54.

17. Bennett AL, Brown JB, Derchak PA, Di Marzo M, Edwards ST. Health and safety guidelines for firefighter training. Paper presented at: Center for Firefighter Safety Research and Development Maryland Fire and Rescue Institute. University of Maryland, College Park. 2006; 13-14, 38-39, 62, 70.

18. Espinosa N, Contreras M. Safety and performance implications of hydration, core body temperature and post-incidence rehabilitation. Orange County Fire Authority, California, 2007.

19. Smith DL, Goldstein E, Petruzzello SJ. Firefighter Fatalities and Injuries: The Role of Heat Stress and PPE. Urban-Champaign, IL: University of Illinois Firefighter Life Safety Research Center. 2008.

20. Melius J. Occupational health for firefighters. Occup Med. 2001;16(1):101-8.

21. Walker A, Driller M, Argus C, Cooke J, Rattray B. The ageing Australian firefighter: an argument for age-based recruitment and fitness standards for urban fire services. Ergonomics. 2014;57:612-21.

22. Jansson A, Segesten K, Mattsson B. Post-traumatic stress among Swedish ambulance personnel. Emergency Medicine Journal. 2003;20:79-84.

23. Violanti JM, Fekedulegn D, Hartley T, Andrew ME, Charles L. E, Mnatsakanova A, Burchfiel CM. Police trauma and cardiovascular disease: association between PTSD symptoms and metabolic syndrome. Int J Emerg Ment Health. 2006;8(4):227-37.

24. Fahy RF, LeBlanc PR, Molis JL, Firefighters fatalities in the United States-2015. National Fire Protection Association. 2016.

25. Soteriades ES, Kawachi I, Liarokapis D, Christiani DC, Kales SN. Obesity and risk of job disability in male firefighters. Occup Med. 2008;58:245-50.

26. Elliot DL, Goldberg L, Kuehl KS, Moe EL, Breger RK, Pickering MA. The PHLAME (Promoting Healthy Lifestyles: Alternative models' Effects) firefighter study: outcomes of two models of behavior change. J Occup Environ Med. 2007;49:204-13.

27. Soteriades ES, Hauser R, Kawachi I, Liarokapis D, Christiani DC, Kales SN. Obesity and cardiovascular disease risk factors in firefighters: a prospective cohort study. Obesity Research. 2005;13:1756-63.

28. Karter MJ, Molis JL. U.S. firefighter injuries in 2009. NFPA Journal. 2010; 4:70-6. 
29. Poplin GS, Harris RB, Pollack KM, Peate WF, Burgess JL. Beyond the fireground: injuries in the fire service. Injury Prevention. 2012;18:228-33.

30. Lee DJ, Fleming LE, Gomez-Marín O, LeBlanc W. Risk of hospitalization among firefighters: The national health interview survey, 1986-1994. Am J Public Health. 2004;94:1938-9.

31. Hootman JM, Macera CA, Ainsworth BE, Martin M, Addy CL, Blair SN. Association among physical activity level, cardiorespiratory fitness, and risk of musculoskeletal injury. Am J Epidemiol. 2001;154(3):251-8.

32. Rhea M, Alvar B, Gray R. Physical fitness and job performance of firefighters. J Strength Cond Res. 2004;18(2):348-52.

33. Rorke S. Issues in physical readiness evaluations for physically demanding occupations. Journal of the Ergonomics Society of Southern Africa. 2002;14(1):27-36.

34. Sharkey B. Development and validation of a job-related work capacity test for wildland firefighters. International Association of Wildland Fire Conference. Sydney, Australia: 1999.

35. McLennan J, Birch A. Profiles of Australia's volunteer firefighters. Bushfire CRC and Latrobe University, Bundoora, Victoria: 2004; 3-6.

36. Lord C, Netto K, Petersen A, Nichols D, Drain J, Phillips M, Aisbett B. Validating "fit for duty" tests for Australian volunteer fire fighters suppressing bushfires. Appl Ergon. 2012;43(1):191-7.

37. Sothmann M, Gebhardt D, Baker T, Kastello G, Sheppard V. Performance requirements of physically strenuous occupations: validating minimum standards for muscular strength and endurance. Ergonomics. 2004;47(8):864-75.

38. Williams-Bell MF, Villar R, Sharratt MT, Hughson RL. Physiological demands of the firefighter candidate physical ability test. MedSci Sports Exerc. 2009;41(3):653-62.

39. Mendenhall D, Moffatt S, Williams T, Reeves M, Greeson J, Shelton CS, Stahl H, Zollinger TW, Saywell RM, Muegge C. Validation of a physical work performance evaluation for incumbent firefighters. Fire Engineering. 2005;158(12):51-8.

40. Boyd L, Rogers T, Docherty D, Petersen S. Variability in performance on a work simulation test of physical fitness for firefighters. Appl Physiol Nutr Metab. 2015;40(4):364-70.

41. Fullagar HHK, Sampson JA, Mott BJ, Burdon CA, Taylor NAS, Groeller H. Employment standards for Australian urban firefighters: Part 4: Physical aptitude tests and standards. J Occup Environ Med. 2015;57(10):1092-7.

42. Nazari G, MacDermid JC, Sinden KE, Overend TJ. The Relationship between Physical Fitness and Simulated Firefighting Task Performance. Rehabil Res Pract. 2018; Hindawi, https://doi.org/10.1155/2018/3234176

43. Claessens AL, van Langendonck L, Moons D, Vandewiele F. Physical fitness of professional firemen. Kinesiology. 2003;35(2):119-30.

44. Subramaniam C, Ali H, Shamsudin FM. Influence of physical ability on initlial emergency response performance. Disaster Prev Manag. 2012;21(5):556-71.

45. https://sjp.pwn.pl/slowniki/uraz.html

46. Dobosz J. Tabele punktacyjne testów Eurofit, Międzynarodowego i Coopera dla uczniów i uczennic gimnazjów oraz szkół ponadgimnazjalnych. AWF Warszawa. 2012;9-15.

47. Eurofit - Europejski Test Sprawności Fizycznej, AWF, Kraków 1989.

48. Rozporządzenie Ministra Spraw Wewnętrznych i Administracji z dnia 27 października 2005 r. w sprawie zakresu, trybu i częstotliwości przeprowadzania okresowych profilaktycznych badań lekarskich oraz okresowej oceny sprawności fizycznej strażaka Państwowej Straży Pożarnej

49. Bowling A. Research methods in health. Investigating health and health services. Buckingham: Open University Press, Philadelphia, 2002.

50. Jitnarin N, Poston WSC, Haddock CK, Jahnke SA, Day RS. Accuracy of body mass index-defined obesity status in US firefighters. Saf Health Work. 2014;5:161-4.

51. Williford HN, Duey WJ, Olson MS, Howard R, Wang N. Relationship between fire fighting suppression tasks and physical fitness. Ergonomics. 1999;42(9):1179-86.

52. Alasagheirin MH, Clark MK, Ramey SL, Grueskin EF. Body mass index misclassification of obesity among community police officers. AAOHN J. 2011;59:469-75.

53. Jitnarin N, Poston WSC, Haddock CK, Jahnke S, Tuley BC. Accuracy of body mass index-defined overweight in fire fighters. Occup Med. 2013;63:227-30.

54. Poplin GS, Ro DJ, Peate W, Harris RB, Burgess JL. The association of aerobic fitness with injuries in the fire service. Am J Epidemiol. 2014;179(2):149-55.

55. Griffin SC, Regan TL, Harber P, Lutz EA, Hu C, Peate WF, Burgess JL. Evaluation of a fitness intervention for new firefighters: injury reduction and economic benefits; Inj Prev. 2015;22:181-8. 